\title{
Missing Body before the Law: bp Nichol's The Martyrology and the Poetics of Language Writing Revisited
}

\author{
Karlyn Koh
}

\section{ADN et le corps manquant dans l'avant-garde poétique de bp Nichol}

A travers une analyse de La martyrologie de bp Nichol et de certaines critiques entourant cette oeuvre, Karlyn Koh soulève trois questions concernant la construction de l'Avant-garde poétique canadienne en tentant d'aborder la possibilité de déconstruction offerte par cette poétique. Quelles sont les limites de l'argumentation pour une subjectivité polysémique, "illimitée", et "radicale"? Dans La martyrologie, Koh suggère que la masculinité est décrétée par la négation et que le "corps manquant" récupère la perte de son "identité" dans le secret et par la "perte". En second lieu, elle demande comment l'écriture autobiographique de l'histoire de la nation et de la géographie de Nichol a engagé des formulations critiques qui perpétuent un culte de "Génie" romantique ("genius loci"). Finalement, elle cherche à rendre compte du " $c$ " manquant dans l'oeuvre de Nichol et dans l'avant-garde poétique canadienne en général.

A figure enigmatically confronts the reader of the 1987 edition of Book Six of bp Nichol's The Martyrology: a figure whose face is hidden on the front cover, and whose back we see on the back cover. The words on the first page of the book read: "a counting" - a duplicitous phrase, as some critics have noted, which alludes to the "missing $c$," the absence, that hovers over the cover of the book and that suffuses The Martyrology. ${ }^{1}$

A face is covered, identity is masked and framed by loss. Such is the function of the uncapitalized " $\mathrm{i}$ " in The Martyrology, according to its critics. Nichol's unfinished long poem - begun in 1967 and spanning more than nine books $\rightarrow$ has often been cited as a radical text without closure, in which the anti-authoritative " $i$ " works as a "symbolic de-privileging of the pronoun" (Davey 41), and is neither sovereign nor unitary. In other words, Nichol's poetics has often been cited for its radical "deconstruction $^{\prime 2}$ of the subject and indeed, of the very nature of identity, through the exploration of "the multiplicity of self" (Kamboureli). 
In the following discussion of The Martyrology, I am interested in a form of avant-garde poetics that has been and is still being articulated in the name of a radical political practice. This paper does not aim to dispute the urgency of intervening into the construction of literary subjects in Canada; on the contrary, it suggests that a questioning of the limits of certain critical constructions of avant-garde poetics is overdue and necessary, in order to broaden the scope of precisely how "subjectivity" and poetic practice are formulated. Implicit in this paper is a questioning of the unchanging discourse on the "subject" and "self" in (English-Canadian) avant-garde writing, variously termed as "oppositional poetics" and "language centred writing," of which The Martyrology is but one of several (and varied) pivotal texts. While keenly interested in the revolutionary nature of poetic language, and avowedly committed to the "social context," much of the writing about poetics in Canada - which seek to challenge the homogeneity and containment of differences in Canadian nationalist literature ("CanLit," as it is often dubbed) - seem inflexible in their formulations of theories of language, signification and identity. This seems particularly curious especially when resistance to representational language is seen as not merely aesthetic, but as a political strategy, in its decentering of a central authorial position, and in its questioning of the ways by which language structures subjectivity. In what sense is poetic language subversive of dominant ways of reading and writing, and does this poetics foreclose the possibility of resistance to cultural norms in its reconfiguration of "identity" in all its multiplicity?

How has such poetics, to which I am linking The Martyrology, been formulated? By opening language to a more diverse signifying practice which integrates the sign, the subject and place in a text. The "subject-inprocess" - never homogenous nor determinate - is hence in interaction with the social, or "contexts." This open text thus engages the reader at a very subjective and context-specific level as well at the level of the play of signifiers. Such a poetics, we are told, is to be found in bp Nichol's The Martyrology.

Present-day articulations of poetic theory seem to need to maintain the myths of its revolutionary origins which may be unquestionably reproduced in critical appraisals of poetic works by other writers, in order to incorporate the excluded (always multiplicitous) identities of "race, class and gender." This is to say, "female subjectivities" and "racialized subjectivities" - akin to the heterogeneous, fluid and precar- 
ious " $\mathrm{i}$ "'s - are accounted for as if the feminine and non-white are not already naturalized at the heart of this poetic discourse. ${ }^{3}$ Might these critical practices mirror those very assimilative moves of multicultural and nationalist literary constructions they decry by producing precisely those excluded identities? ${ }^{4}$ While critical efforts to counter the male and white coded poetics have typically sought other subjects to address these exclusions, my paper seeks to understand this poetics as founded on the basis of such (muted) "other" sex and race.

In his conversation with Steve McCaffrey, Nichol observes that the fluidity of pronouns (especially the " $i$ ") and nouns has always fascinated him. His vision of "pataphysical" writing - related to what he terms as "schizophrenic logic" - consists "of making image jumps on the basis of different meanings nouns could have" ("In ten tion" $^{\text {sion). }}{ }^{5}$ This concept, he notes, was confirmed when he encountered Jacques Lacan's work, "where, in a footnote he remarked how in the speech of psychotics the signified slid beneath the signifier. That fluidity of nouns [and] pronouns, of naming and the range of what we think of as the subject, the exploration of that remains, for me, perennially fascinating and perennially rewarding" (86). In such poetics, linguistic play releases another text that lies hidden, repressed within language. McCaffrey, in his discussion of The Martyrology, calls such writing (his own included) "paragrammatic," which is not "far from ... the system of the unconscious, for the implication of the paragram (i.e. meaning's emergence out of a different meaning both of which share common graphic or acoustic components) is that a unitary point of reference can no longer operate as a binding agent of closure" (69). Such poetics is concerned with antisemantics - or designification - which subverts the order of meaning by foregrounding the materiality of the sign (the letter, in this case) and thus indicating its arbitrariness, "madness," and anti-thesis to meaning itself.

The paragrammatic reversals of DNA in $\mathrm{D}(\mathrm{o}) \mathrm{N}(\mathrm{n}) \mathrm{A}, \mathrm{C}(\mathrm{a}) \mathrm{N}(\mathrm{a}) \mathrm{D}(\mathrm{a})$, $\mathrm{C}^{\prime} \mathrm{ND}$, St.And and Spadina-Dina Madi, among others as McCaffrey points out, reveal - cryptonymically - an incoherent mythic writing of a personal and national life, composed as and in the "missing $\mathrm{c}^{\prime}$ in The Martyrology. To read The Martyrology as a cryptonymic text would entail moving across the signifieds and searching for semantic displacements which, through series of embeddings and conversions, cover over the emergence of signification. These processes have been termed by Nicolas Abraham and Maria Torok as "demetaphorization," "anti- 
metaphor," or "designification." They are interested in the move from the collapse of meaning (designification) to nonapparent sources of signification (anasemia).

The fetish status of DNA in The Martyrology can be read as an anasemic writing of entombed loss and displacement. However, what is the investment or value of exclusions sealed in the cryptic vault named The Martyrology, where the Subject is lost and dis-assembled? In such a indissoluble distance between the " $\mathrm{I}$ " and the "me," the subject and object of reflexivity, contradictions intrinsic to psychoanalysis reside. Nicolas Abraham's essay, "The Shell and the Kernel," is very much concerned with casting the space between the "me" and the " $\mathrm{I}$ " - the anasemic discourse in which psychoanalysis speaks - as sexualized. This is one crucial aspect of the " $\mathrm{i}$ " that is consistently elided in readings of The Martyrology. Abraham argues that the anasemic relation between the organic Kernel and the psychic Shell-in which periphery of the primary Kernel is doubly nucleic - is such that the symptomatic memory traces between the Envelope and the Kernel are actively instigated by the postulation of the nucleic Masculinity of Sex. Thus the Kernel's relation to the Envelope is, by anasemia, "sexual to the extent that every fantasy aspires to have contact with the Unconscious and thereby concerns the phallus" (90). The memory traces quivering in the series of embeddings - "the missing c" in Nichol's work - are inscribed in the intermediary between the Shell and the Kernel, and are active emissaries on different nucleoperipheral frontiers. Mourned as absences in the mausoleum of identity, these traces may paradoxically be understood as transphenomenal forces born in the conflictual relation between the Kernel and the Shell.

In The Martyrology Book Four (1976; 1993), we read:

(the desire becomes stronger to stretch out, explain myself, which makes the plain ex, no longer clear, $i$ want a different ear, a he like me, a she where the $\mathrm{s}$ is (in correct relation to)

$$
\text { he/i/she }
$$

(why is the s the

feminizer?, makes the $i$ is, births it, gives it its being, carries the he in the body of its word, the men inside women, the me in both of them) EQUATIONAL DEVELOPMENT: HE / IS / HE such minimal movements to seek truth in (steve said 'you'll be accused of shallowness' (hallowness feminized?))) 
Situated between the masculine (father) and the feminine (mother),

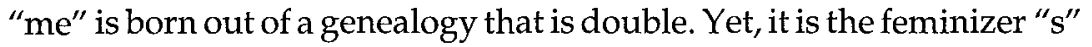
that activates the " $\mathrm{i}$ " to "is." That is, the not-yet-born " $\mathrm{i}$ " requires " $\mathrm{s}(\mathrm{he})$ " in order to be (re)generated. Desiring "a he like me" (unlike He the dead Father), the Unconscious Kernel only knows the male sex, yet conjures the living, birthing maternal Envelope to ensure its own resurrection.

Therefore, the anasemic tension between : "he/i/she" and "HE/ IS / $\mathrm{HE}^{\prime}$ " reveals a primary designification of " $\mathrm{i}$ " - born out of "he" and "she," the "me in both of them" - that is given a "different ear" premised on the missing "s." So "he" is dissociated from the dead letter "he" and carried into "the body of its word" by the maternal. This "equational development," far from simply being about the feminizer "s," requires that "me" /" $\mathrm{i}$ " be specifically masculinized at its very inception.

Cast within a symbolic order where the Unconscious Kernel is figured as phallic for both men and women, femininity is thus endowed with penis-envy as an instrument of its own repression, according to Abraham. Nichol's repeated return to the feminine line bears witness to the attempt to transgress this code, to "ward off contact with the Phallus of one's own Unconscious" (Abraham 89), but also bears the marks of the guilt and unspeakability that goes with the (attempted) transgression. In other words, the de-signification of the phallic casts the nets of its resignification through identification with the feminine.

Is the maternal ventriloquising in the male to be read as an imaginary identification which is outside the symbolic? "The symbolic," Judith Butler writes, "marks the body by sex through threatening that body, through the deployment/production of a imaginary threat, a castration, a privation of a bodily part ..." (Bodies that Matter 101). Nichol's poetics articulates a resistance to the symbolic mark of the masculine, one which is haunted by the imaginary threat of castration. This symbolic mark, according to Butler, also assumes "a certain inevitable failure, a failure to have and a yearning to have a penis envy which is not the opposite of the fear of castration, but its very presupposition." The "s" is produced in relation to the masculine to symbolize precisely the wish for and loss of the phallus; " $\mathrm{s}$ " + "he" reassures the loss that haunts the "he" / $\mathrm{i}$ " by guaranteeing the phallic status of the " $\mathrm{i} /(\mathrm{s}) / \mathrm{he}$ " even as this guarantee can be relinquished for the threat of castration. The feminine position precisely consolidates the masculine possession of the phallus even as it threatens it. The identification with the symbolic position of the castrated feminine 
(as only "s" and "wo," needing the masculine to complete it) in turn produces "the displaced version of the (imaginary) father to desire" (Bodies that Matter 102). If The Martyrology recovers the feminine and maternal, it does so in compliance with the symbolic:

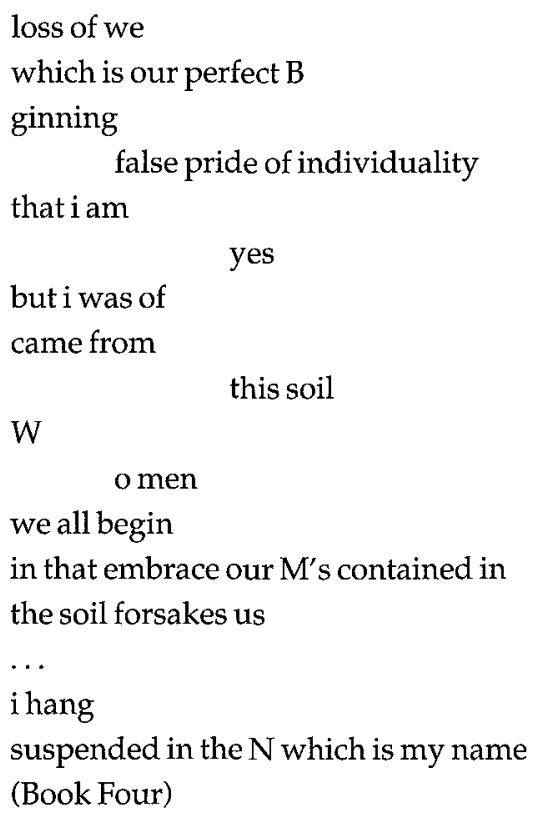

As a subversion of the symbolic, this poetics creates the possibility of the multiplicitous " $\mathrm{i}$ " - in its evanescent shuttlings between the Shell and the Kernel - which displaces the paternal law. However, the return to language's fundamental indeterminacy is premised by the very law it wishes to undermine. Which is to say, language becomes the "ground grammar," and the "other"-"mother" recognition functions as the fecund ground ("soil") in which the One gets lost and also finds One-self. In the invocation of his grandmother Agnes in "The Grammar Trilogy," (Hours 20 and 21, "Book of Hours," Book 6), Nichol writes:

$$
\begin{aligned}
& \left.\begin{array}{l}
\text { bio } \\
\text { geo }
\end{array}\right\} \text { graphy } \\
& \text { writing a self } \\
& \text { a country }
\end{aligned}
$$

landscape a can be in 
grammar

: the relations of words in

a sentence

she is my grammar

her name is Agnes

ground grandma

you were the gave in my give

a love of women

flows from what you taught me

In the re-naming of the maternal and feminine line of his family, "she" "lives" on in memory as the " $\mathrm{s}$ " - the living language and the language of the living feminine installed against death and the dead. Regardless of its postulated heterogeneity, the figuration of the maternal body ("ground grammar") within the intertwined linguistic and social (kinship) relations, recapitulates the compulsory cultural construction of the female body as maternal. ${ }^{6}$

The lost phallus which desires to be reclaimed is then effected through the living feminine, through the "chance collisions of unknown bodies" ("Assumptions") in the "gramma(r)" of language. This spectral loss is paradoxically the tomb of the other buried alive in the living, that leaves a gap within the living. In one section of "Assumptions" (Gifts: Book $7 \mathcal{E}$ [1990]) we read:

names

lists

Captain Samuel Parcher

born 1774

when an American was still an Englishman

fathered Elias Parcher

1799

married

Polly Mary Fuller

1824

one of my great great great grandmothers

rumoured to be 
one-half cherokee

out of her mother Polly

a full blood

born circa 1780

The "puncertainty" of the "biological" is traced through the "pollymorphous" maternal line, and "in the endless naming/ the polly-if-any/ if in which the $i$ lives too." The other sexed and raced is revealed as the living, polymorphous inciter of the subject's difference. Their recuperation and re-creation (as paragrammatic dispersals) within memory mark the condition of the specter haunting the subject - the specter of the subject's own destabilization. In its questionings of history and identity, The Martyrology is motivated by an entombed anxiety over race, an anxiety which might be considered as both a desire for and disavowal of whiteness.

Nichol notes that "every poem is simply the history of writing" (Hour 3, "Book of Hours," Book 6), and to that end, has written a history that cannot be absolutely re-traced and that is premised on irreparable loss. It is through writing, as Michel de Certeau argues, that relations with the other are formed, hence opening up the complicity between history and ethnology. A passage in the middle of "Chain 1" of Book Five (1982; 1994) reads:

history

the white man's record

indians had their own legends

saw the white man as interloper

rowed in with death

into their world

as the french viewed the englishers

intruders in the land they'd come to claim

white v.s. white

took sides

French \& Huron

English \& Iroquois

H \& I

twisting round of speech

mirrored them

each in each 
we talk of history honouring our claims

what we claimed without honour

set out to "tame" the New World

what was the Old World

with its own legends

we name as fits our purpose

shape language to our own ends

all the lies, dishonour, death \& treason such a use portends

$\mathrm{E} \& \mathrm{~F}$

H\&I natural enemies in the 1620 's

Here "history" - writing, the "record," writing as archive (Certeau 216) - is installed against "legend" - "twisting round of speech." The unfolding of this rift between civilization and whiteness, and its "other" connects Nichol's work with the on-going re-definitions of a Canadian identity that vacillate spatially and temporally between the "here" and "there," the "then" and "now" bipolarities of Western ideological and material imperialism.

Stained by the "lies, dishonour, death \& treason," history, the "white man's record," as re-written in this chain and in the long poem, goes through a series of interesting metamorphoses. The unknown "truths" and "mystery" lying behind "history," the illegible intelligibility of the paragrammatic "drifts and shifts" in the sentence signal a move back to the oral, nature, pre-history, and the maternal. In the same chain (1) further on, we read:

reversing a thrust of history

the celtic was carried there (Canada) by Brendan

500 a.d. or (probably) earlier

stone circles on the prairie near Medicine Hat

cairns found inland in Labrador

the mind circles some truths i've circled before

On the one hand, the First Nations, who "had their own legends," mirror the "white man" as its absolute other. On the other, there is a return to a space and time in Europe prior to history and brought to Canada. The "New World," cast first as the primitive."Old World" where the natives had "their own legends," is marked off from the "Old World" (of mythic Europe) by the dividing line figured as the Atlantic Ocean (crossing the 
"c" and "meme- eau"-ry trace) in ethnographic texts (as discussed by Certeau) as well as The Martyrology. "The mind circles some truths i've circled before" ("Chain 1," Book Five), and crosses this divide again, so that "the other returns to the same" (Certeau 219).

Hence the former "Old World" attributed to the " $\mathrm{H} \& \mathrm{I}$ " is forgotten as the "Old World" (here, of civilization proper) is re-located and discovered afresh in the "New World" ("we stress the newness of our be"). The mirror " $\mathrm{E} \& \mathrm{~F}^{\prime} /$ " $\mathrm{H} \& \mathrm{I}$ " are revealed to be images of the same. Transferred to the here-and-now of this place without memory ${ }^{7}$ Canada - this "civilized primitive," the multiple " $\mathrm{i}$ " of The Martyrology, returns again and again, passing through the oceanic divide ("meme eau"), back into Western discourse, via the "primitive" other who is subtly denuded and stripped so as to furnish the mythic writing of "civilization" in the then-Old-now-New-World.

Does "subversion" in The Martyrology assume a pre-Symbolic that is instinctually and independently outside of hegemonic cultural productions? And does the theory of heterogeneity function in the same way as the law of identity it opposes? In her critique of Julia Kristeva's theory of the semiotic, Butler notes that "all manner of things 'primitive' and 'Oriental' [in Kristeva's work] are summarily subordinated to the principle of the maternal body ... [which] raises the question of whether, ironically, multiplicity has become a univocal signifier" (Gender Trouble 89). Can Nichol's poetics, and more importantly, the critical production of radical poetic practices (as alluded to at the beginning of this paper), be open to such a critique as well?

I am suggesting that Nichol's poetics partakes in producing (rather than disrupting) as repressed that which, through poetic language, may reveal the multiple " $\mathrm{i}$ " that displaces the confined unitary subject. Poetic language as discussed here preserves symbolic structuring of culture through the production of naturalized heterogeneity of the femininematernal and primitive as the required outside within the law. Might the work of contesting ways of reading and writing challenge instead the nostalgia for the (purportedly multiple, currently "hybrid" as well) "subject" recuperated for what passes as subversive acts of signification? This challenge may lead one to question the axioms and assumptions of what constitutes "culture" (and its constitutional "outsides") on which such poetics is founded, and what it means to demonstrate or read, in all their heterogeneity, the manifest signs of "racialized poetics," "feminist poetics," "working-class poetics," or "lesbian poetics," for 
example. A challenge, that is to say, that asks whether behind the hidden face lurks an " $\mathrm{T}$ " in search for " $\mathrm{i}$ " $\mathrm{s}$ that are One, represented and seen as the abject and unassimiliable.

\section{Notes}

Thanks to Erin Soros, Chris Bracken and Roy Miki for feedback on the work of which this paper is a revised section. Acknowledgments as well to the Tessera collective for editorial suggestions, and to S.S.H.R.C.C

1 Years for individual books of The Martyrology will be cited when referred to in the essay. Except for the 1987 edition of Book 6, I refer to the facsimile editions (Coach House Press) of The Martyrology. As the books are not paginated, I have referred to named sections (when possible) to indicate the location of quotes.

2 The term "deconstruction" as used by liberal critics in the service of a relativizing politics of interpretation is implicitly in question throughout this paper. This sense of "deconstruction" - which normalizes rather than revolutionizes cultural institutions - is nothing more than a formalism codified as "post-modern" and "post-structural." Gayatri C. Spivak, in critiquing this domestication of deconstruction in the general sense, writes: "It is thus that [deconstruction in the limited and limiting sense] fits into existing ideology of American literary criticism, which has already assimilated phenomenology's privileging of consciousness and is about to assimilate structuralism's apparent scientism.... Deconstruction in [this] narrow sense, no more than a chosen literary methodology, locates [the] signifying or figuring effect in the 'text's' performance and allows the critic authority to disclose the economy of figure and performance" (16). See also Lorraine Weir's critique of certain formulations of English-Canadian postmodernism.

3 For example, Jeff Derkson's and Fred Wah's essays.

4 See Michel Foucault's concept of power and the repressive hypothesis.

5 On "'pataphysics," see Nichol's "The 'Pata of Letter Feet."

6 See Butler's Gender Trouble.

7 Stephen Scobie notes that Book Six of The Martyrology tells of the voyage of two early Christian saints "across the sea (the middle c, the missing c of 'a counting') to a place with as yet no name, no history, no memory, no mourning: Canada" (276). 


\section{Works Cited}

Abraham, Nicolas. "The Shell and the Kernel: The Scope and

Originality of Freudian Psychoanalysis." Rpt. The Shell and the Kernel [with Maria Torok]. Vol. I. Trans. N. Rand. Chicago: Chicago UP, 1994.

— , and Maria Torok. The WolfMan's Magic Word. Trans. N. Rand. Minneapolis: Minnesota UP, 1986.

Butler, Judith. Bodies that Matter: On the Discursive Limits of "Sex." New York: Routledge, 1993.

- Gender Trouble: Feminism and the Subversion of Identity. New York: Routledge, 1990.

Certeau, Michel de. The Writing of History. Trans. T. Conley. New York: Columbia UP, 1988.

Davey, Frank. "Exegesis/ Eggs à Jesus: The Martyrology as a Text in Crisis," in Tracing the Paths, ed. Miki:38-51.

Derkson, Jeff. "Making Race Opaque: Fred Wah's Poetics of Opposition and Differentiation." West Coast Line 18.29.3 (Winter 1995-6): 63-76.

Foucault, Michel. The History of Sexuality: An Introduction. Vol. I. Trans.

R. Hurley. New York: Vintage, 1990.

Kamboureli, Smaro. "'there's so much i': Self and Genre in The Martyrology," in Tracing the Paths, ed. Miki: 95-117.

McCaffrey, Steve. "The Martyrology as Paragram." North of Intention:

Critical Writings 1973-1986. New York/Toronto: Roof Books/Nightwood, 1986.58-76.

—. "In Tension: Dialoguing with bp," in Tracing the Paths, ed. Miki: 72-94.

Miki, Roy, ed. Tracing the Paths: Reading (Writing The Martyrology. Vancouver: Talonbooks and Line, 1988.

Nichol, bp. The Martyrology Books 3 \& 4. 1976. Toronto: Coach House, 1993.

—. The Martyrology Book 5. 1982. Toronto: Coach House, 1994.

—. The Martyrology Book Six Books. 1987. Toronto: Coach House, 1994.

—. The Martyrology Book(s) 7 \&. Toronto: Coach House, 1990.

—. "The 'Pata of Letter Feet, or, The English Written Character as a Medium for Poetry." Open Letter 6.1 (Spring 1985): 79-95.

Scobie, Stephen. "On Dangerous Ground: Two Essays on Six Books," in Tracing the Paths, ed. Miki: 260-77. 
Spivak, Gayatri Chakravorty. "Finding Feminist Readings: DanteYeats." In Other Worlds: Essays in Cultural Politics. New York: Routledge, 1988. 15-29.

Wah, Fred. "Poetics of the Potent." Open Letter 9.2 (Spring 1995): 75-87. Weir, Lorraine. "Normalizing the Subject: Linda Hutcheon and the English-Canadian Postmodern." Canadian Canons: Essays in Literary Value. Ed. R. Lecker. Toronto: Toronto UP, 1991. 180-95. 